\title{
EXTENDING THE SCOPE OF PROPRIETARY REMEDIES TO RECOVERY OF PURE PROFITS FROM SUCCESSFUL INVESTMENT OF BRIBES: THE ENDGAME IN LISTER $V$ STUBBS
}

\section{Mohsin Hingun and Aiman Nariman Mohd Sulaiman} Assoc Professor, Dept of Civil Law, AIKOL, International Islamic University Malaysia, Kuala Lumpur, Malaysia.
Email: mohsin@iium.edu.my.

Professor, Dept of Civil Law, AIKOL, International Islamic University Malaysia, Kuala Lumpur, Malaysia. Email: aimann@iium.edu.my.

\begin{abstract}
For more than a century Lister v Stubbs (1890) 45 Ch D 1 stood as authoritative Court of Appeal judgment denying the recovery of profits acquired from the successful investment of gains obtained in breach of fiduciary duties. The rule was rationalized on the basis that while the claimant was entitled to the proceeds so unlawfully obtained, he lacked any form of proprietary title to the profits accumulated by the defaulting fiduciary. The harsh reality of the rule produced an unfair outcome to the claimant and the Privy Council refused to apply it in Attorney-General for Hong Kong v Reid [1994] 1 AC 324. The rule also fell out of favour in other leading commonwealth jurisdictions and recently the English courts at all levels had the opportunity to reassess its relevance when the Supreme Court in FHR European Ventures LLP and others v Cedar Capital Partners LLC [2014] 4 All ER 79 consigned it to oblivion. The objective of this paper is to analyse the merits and the deficiencies of the rule and show how the judges of the English courts were prepared to act on policy ground, in comity with other common law jurisdictions in upholding justice in a borderless world.
\end{abstract}

Keywords: breach of Fiduciary duty; Accounts of profits; Proprietary interests; Recovery of pure profits.

\section{Introduction}

FHR European Ventures LLP and others $v$ Cedar Capital Partners $L L C{ }^{1}$ reached the Supreme Court mid 2014 against the conflicting background of the opinion of the Privy Council in Attorney-General for Hong Kong $v$ Reid $^{2}$ which had refused to follow Lister $v$ Stubbs $^{3}$ and the line of authorities which applied the Lister 
principle culminating in the decision of the Court of Appeal in Sinclair Investments (UK) Ltd v Versailles Trade Finance Ltd. $^{4}$

The decisions can be divided into two broad categories: The non-proprietary school and the proprietary school. Lister and the cases following it represent the non proprietary category under which a fiduciary who receives a bribe or a secret commission is personally liable to restore it to the beneficiary. Reid represents the proprietary school pursuant to which all benefits accruing to a fiduciary in breach of his fiduciary duty are held on trust for the principal irrespective of the whether the opportunity was one available to the principal or whether the benefit was an unauthorised secret commission. The source of the profit or asset obtained is not as important as the fact it was obtained in breach of fiduciary duty.

By 2013, the leading common law jurisdictions, including USA, Canada, Australia, New Zealand and Singapore followed the proprietary school of thought. Although attempts were made towards this path in UK, the matter was not settled until the Court of Appeal in FHR European Ventures ruled in favour of a proprietary remedy which was finally endorsed by the Supreme Court.

\section{Sinclair Investments (UK) Ltd v Versailles Trade Finance Ltd}

In Sinclair the Master of the Rolls was not in favour of Reid on the ground there was a fundamental difference between a fiduciary enriching himself at the expense of a beneficiary on the one hand and on the other hand by doing a wrong to the beneficiary ${ }^{5}$ :

"In cases where a fiduciary takes for himself an asset which, if he chose to take, he was under a duty to take for the beneficiary, it is easy to see why the asset should be treated as the property of the beneficiary. However, a bribe paid to a fiduciary could not possibly be said to be an asset which the fiduciary was under a duty to take for the beneficiary. There can thus be said to be a fundamental distinction between (i) a fiduciary enriching himself by depriving a claimant of an asset and (ii) a fiduciary enriching himself by doing a wrong to the claimant."

The decision in Sinclair was based on a number of Court of Appeal decisions ${ }^{6}$ which preferred not to follow Reid. However, in 2012 a Full Court of the Federal Court of Australia in Grimaldi v Chameleon Mining NL $(\text { No.2 })^{7}$ rejected Sinclair and Lister in favour of Reid, but stressing that in Australia the imposition of a proprietary constructive trust is a discretionary remedy and not one automatically imposed once a breach of duty claim has been proven. FHR European Ventures reached the English courts when Sinclair had just reaffirmed Lister and was critical of Reid whereas other jurisdictions had moved away from Lister in favour of Reid.

\section{The Facts and History FHR European Ventures ${ }^{8}$}

In 2004, FHR purchased a hotel company for $€ 211.5$ million. Cedar was FHR's agent during the negotiation process. Unknown to FHR, Cedar had also entered into a brokerage agreement with the seller pursuant to which it received $€ 10$ million. FHR issued proceedings against Cedar to recover the 'secret commission'. The High Court found in favour of FHR on the ground that Cedar had failed to make proper disclosure of the brokerage agreement to FHR but being bound by Sinclair refused to grant a proprietary remedy to FHR, instead holding that a constructive trust was created for the benefit of FHR when Cedar received the commission. The Court of Appeal in a unanimous judgment found in favour of FHR and Cedar appealed to

\footnotetext{
${ }^{4}$ [2011] 4 All ER 335

${ }^{5}$ Ibid, at [80]

${ }^{6}$ Metropolitan Bank v Heiron (1880) L.R. 5 Ex. D. 319, CA; Lister \& Co. v Stubbs

(1890) 45 Ch.D. 1, CA; Gwembe Valley Development Co. Ltd v Koshy [2004] 1 B.C.L.C. 131 and Halton International Inc. v Guernroy Ltd [2006] W.T.L.R. 1241

${ }^{7}$ [2012] FCAFC 6 at [569]-[584].

${ }^{8}$ For a more comprehensive account see Supreme Court Judgment, Note 1 at [2] - [4]
} 
the Supreme Court challenging the creation of a constructive trust and the application of a proprietary remedy on the facts.

After two hearings in the High Court Simon $\mathrm{J}^{9}$ concluded that he should (i) make a declaration of liability for breach of fiduciary duty on the part of Cedar for having failed to obtain the claimants' fully informed consent in respect of the EUR 10m, and (ii) order Cedar to pay such sum to the claimants, but ${ }^{10}$ (iii) refused to grant the claimants a proprietary remedy in respect of the moneys.

\section{Judgment of the Court of Appeal}

FHR European Ventures LLP and others $v$ Mankarious and others ${ }^{11}$ reached the Court of Appeal for judgment early 2014 where Etherton C referred to the categorisation ${ }^{12}$ in Sinclair, of situations where a fiduciary benefits in breach of fiduciary duty and explained it as follows ${ }^{13}$ :

The first category (Category 1) is where the benefit is or was an asset belonging beneficially to the principal (most obviously where the fiduciary has gained the benefit by misappropriating or misapplying the principal's property). The second category (Category 2) is where the benefit has been obtained by the fiduciary by taking an advantage of an opportunity which was properly that of the principal. The third category (Category 3 ) is all other cases. According to the analysis and conclusion of Lord Neuberger, the situations in Categories 1 and 2 give rise to a constructive trust [which gives the principal a proprietary claim over the assets in question], but those in Category 3 do not.

At the conclusion of his judgment he ruled that on the facts the case fell within category 2 and Lister was a borderline case falling between category 2 and category 3. He opined that if not Parliament, the Supreme Court was the proper authority 'to revisit the very many longstanding decisions in category 2 cases and to provide an overhaul of this entire area of the law of constructive trusts...'

It seems the difficulty rests in reconciling the category 2 cases in the light of the rule in Lister. For example in Keech $v$ Sandford ${ }^{14}$ the trustee who renewed a trust lease for his own benefit was ordered to hold it on a constructive trust for the beneficiary notwithstanding the fact that the landlord would not have renewed it for the infant beneficiary. Again in Boardman v Phipps ${ }^{15}$ the beneficiary could not avail itself of an opportunity to acquire a controlling interest in a company without the court's permission, whereupon the fiduciary took advantage of it and ultimately reorganised the company as a result of which all the shareholders enjoyed substantial benefit. Although Boardman had reached the House of Lords, Etherton C relied on the first instance of Wilberforce $\mathbf{J}$ to rationalise its classification as a category 2 case. Wilberforce $\mathbf{J}$ had declared that the defendants were constructive trustees for the plaintiff who were entitled to an account.

Drawing support from Boardman the Court of Appeal unanimously agreed that the fee paid to Cedar did not fall in the first category. With the exception of Pill LJ who expressed 'reservations' ${ }^{16}$ it was also agreed that it did fall in category 2 as a diversion of the corporate opportunity to buy at a lower price. However Etherton C was at pains to express concern over 'the very considerable difficulties inherent in the analysis in Sinclair and the decision in Lister in marking the borderline between cases in Category 2 and those in Category 3. ${ }^{17}$

\footnotetext{
${ }^{9}[2012] 2$ BCLC 39

${ }^{10}[2013] 2$ BCLC 1

${ }^{11}$ [2014] Ch 1

12 Note 4 at $[88-89]$

${ }^{13}$ Note 12 at [83]

${ }^{14}$ (1726) Sel. Cas. Ch. 61

${ }^{15}$ [1967] 2 A.C 46 HL.

16 [69]- [74]

${ }^{17}$ [116]
} 


\section{Judgment of the Supreme Court}

The Court of Appeal decision can be said to have achieved the desired result in consonance with what would have been the result in progressive common law jurisdictions not adhering to the Lister rule but the classification of the case in category 2 defied clarity and progression in this important field of equity. It was commented that 'FHR might be analysed more comfortably as a case falling in the first category. That option is probably available only to the Supreme Court (or Parliament), which might also take the opportunity to reconsider whether constructive trusts should be excluded from category three.'(Chambers, 2013)

Indeed in less than a year FHR European Ventures $v$ Cedar Capital Partners ${ }^{18}$ reached the Supreme Court which dealt the final blow to Lister and cases following it culminating in Sinclair. In the leading judgment of Lord Neuberger the following established principles were identified:

First, an agent owes a fiduciary duty to his principal ... Secondly, as a result, an agent 'must not make a profit out of his trust' and 'must not place himself in a position in which his duty and his interest may conflict'... Thirdly, '[a] fiduciary who acts for two principals with potentially conflicting interests without the informed consent of both is in breach of the obligation of undivided loyalty; he puts himself in a position where his duty to one principal may conflict with his duty to the other'. Because of the importance which equity attaches to fiduciary duties, such 'informed consent' is only effective if it is given after 'full disclosure'...

Equally well established is the principle of equitable compensation which in "no way depends on fraud or absence of bona fides. ${ }^{19}$ The relief accorded by equity is primarily restitutionary or restorative rather than compensatory ${ }^{20}$ but 'the centrally relevant point for present purposes is that, at least in some cases where an agent acquires a benefit which came to his notice as a result of his fiduciary position ...the principal has a proprietary remedy in addition to his personal remedy against the agent, and the principal can elect between the two remedies. ${ }^{21}$

Keech $v$ Sandford ${ }^{22}$ is an example of a case falling within the ambit of the rule in which it was strictly applied notwithstanding the fact that the landlord would not have renewed the lease in favour of the beneficiary. The rule has been applied in many cases in several jurisdictions and the important issue here is the limits or boundaries of the rule with reference to bribes and secret commissions obtained by a fiduciary in breach of his duties to the detriment of his principal.

His Lordship went on to examine cases and legal articles against $\mathrm{t}^{23}$ the broad application proprietary rule (following Lister) and those in favour ${ }^{24}$ of the rule applicable to cases of bribes and secret commissions (following Reid). As to the rich academic debate, he referred to leading journal articles written by learned authors in the field of equity. After analysing the cases, legal articles and development in other jurisdictions and a careful scrutiny of counsels' submissions, Lord Neuberger was persuaded to depart from the

\footnotetext{
${ }^{18}$ [2014] UKSC 45; [2014] 3 WLR 535

${ }^{19}$ Regal (Hastings) Ltd v Gulliver [1942] 1 All ER 378 at 386, [1967] 2 AC 134 at 144-145

${ }^{20}$ Millett LJ in Bristol and West Building Society v Mothew [1996] 4 All ER 698 at 711, [1998] Ch 1 at 18,

${ }^{21}$ Ibid, at [7]

${ }^{22}$ Note 14

${ }^{23}$ Cases: Metropolitan Bank v Heiron (1880) 5 Ex D 319 (Court of Appeal); Lister \& Co v Stubbs (1890) 45 Ch D 1; Re North Australian Territory Co, Archer's Case [1892] 1 Ch 322; Powell \& Thomas v Evan Jones \& Co [1905] 1 KB 11; A-G's Reference (No 1 of 1985) [1986] 2 All ER 219 at 224, [1986] QB 491; Regal (Hastings) Ltd v Gulliver [1942] 1 All ER 378 at 393, [1967] 2 AC; Sinclair Investments Ltd v Versailles Trade Finance Ltd [2012] Ch 453

Articles: R Goode, "Proprietary liability for secret profits - a reply" (2011) 127 LQR 493; Proprietary Restitutionary Claims in Restitution: Past, Present and Future (1998, ed. Cornish and others) p 69; S Worthington, "Fiduciary Duties and Proprietary Remedies: Addressing the Failure of Equitable Formulae" (2013) 72 CLJ 720.

${ }^{24}$ Cases: Fawcett $v$ Whitehouse (1829) 1 Russ \& M 132; Barker v Harrison (1846) 2 Coll 546; In Re Western of Canada Oil, Lands and Works Co, Carling, Hespeler, and Walsh's Cases (1875) 1 Ch D 115; Re Morvah Consols Tin Mining Co, McKay's Case (1875) 2 Ch D 1; Re Caerphilly Colliery Co, Pearson's Case (1877) 5 Ch D 336 Eden v Ridsdale Rlwy Lamp and Lighting Co Ltd (1889) 23 QBD 368 ; Nant-y-glo and Blaina Ironworks Co v Grave (1878) 12 Ch D 738; Williams v Barton [1927] 2 Ch 9; Morison v Thompson (1874) LR 9 QBD ; Diplock v Blackburn (1811) 3 Camp 43). In Whaley Bridge Calico Printing Co v Green (1879) 5 QBD 109; A-G for Hong Kong v Reid [1994] 1 All ER 1; Daraydan Holdings Ltd $v$ Solland International Ltd [2005] 4 All ER 73 at [75]ff, [2005] Ch 119, Lawrence Collins J indicated that he would follow A-G for Hong Kong $v$ Reid rather than Lister v Stubbs, as did Toulson J in Fyffes Group Ltd v Templeman [2000] 2 Lloyd's Rep 643 at 668-672.

Articles: P Millet, "Bribes and Secret Commissions"[1993] Rest LR 7; P Millett, "Bribes and secret commissions again" (2012) 71 CLJ 583; L Smith in "Constructive trusts and the no-profit rule" (2013) 72 CLJ 260
} 
longstanding but controversial rule in Lister in favour of a broader application of the proprietary rule adopted in Reid for a number of reasons law, policy and harmonisation of the development of common law. ${ }^{25}$

Lister v Stubbs followed the previous Court of Appeal judgment in Metropolitan Bank v Heiron ${ }^{26}$ decided a decade earlier which in turn was based on the House of Lords case of Tyrrell v Bank of London. ${ }^{27}$ Lord Neuberger concluded 'that the law took a wrong turn in Metropolitan Bank v Heiron and Lister $v$ Stubbs, and that those decisions, and any subsequent decisions... and Sinclair Investments (UK) Ltd v Versailles Trade Finance Ltd [2011] 4 All ER 335, [2012] Ch 453), at least in so far as they relied on or followed Metropolitan Bank v Heiron and Lister v Stubbs, should be treated as overruled.' Regarding Tyrrell v Bank of London ${ }^{28}$, he held 'that the many decisions and the practical and policy considerations which favour the wider application of the rule and are discussed above justify our disapproving Tyrrell $v$ Bank of London.'

\section{The Implications of FHR European Ventures}

The decision in FHR European Ventures is bound to have far reaching implications in the law governing breach by fiduciaries:

a) Title to bribes and secret commissions can be asserted by claimants to the detriment of unsecured creditors. Claimants will have two claims against fiduciaries in breach: a proprietary claim which will allow tracing of money claimed into assets acquired by the fiduciary and also a personal claim against the fiduciary.

b) Since the proprietary claim will attempt to recover property impressed with a trust the usual limitation period will not apply to make the action time-barred.

c) A proprietary claim will enable the claimant to apply for Mareva orders to prevent risk of dissipation of assets.

e) It provides guidelines on the development of the law in this field to several common law jurisdictions where the issue has not yet been debated, for example Malaysia.

\section{Conclusion: The Malaysian Position}

Bank Bumiputra Malaysia Bhd \& Anor v Lorrain Osman \& Ors ${ }^{29}$ is the only case where Lister has been discussed in Malaysia but not in great detail. The defendant, Lorrain, acted in breach of his fiduciary duty as director and chairman of a bank and received a sum exceeding $\mathrm{M} \$ 27 \mathrm{~m}$ as secret commissions/bribes. In an application to strike out the statement of claim on the ground that there was no reasonable cause of action, Lorrain argued relying on Lister that since the sum he received was not the bank's property, it was not impressed with a trust and he was not a constructive trustee.

Zakaria Yatim $\mathbf{J}$ discussed a number of cases to reinforce the nature of fiduciary relationship and after examining the judgments in Regal (Hasting) Ltd $v$ Gulliver and Others ${ }^{30}$ and Industrial Development Consultants Ltd $v$ Cooley ${ }^{31}$ he concluded that 'from the authorities cited above, I find that the plaintiffs are entitled to seek a declaration that Lorrain received the sum of $M \$ 27,652,853.06$ as constructive trustee for them. ${ }^{32}$ Unfortunately there was no discussion on the proprietary nature of such bribes and secret commission. Given the absence of analysis on the nature of the claim in the case, it is not authority for the proposition that bribes and secret commissions taken by a fiduciary can be impressed with a constructive

\footnotetext{
25 [33-45]

${ }^{26}$ (1880) 5 Ex D 319

${ }^{27}$ (1862) $10 \mathrm{HL}$ Cas 26

${ }^{28}$ (1862) 10 HL Cas 26, (1862) 11 ER 934

${ }^{29}$ [1987] 2 MLJ 633

30 [1942] 1 All ER 378

31 [1972] 1 WLR 443

${ }^{32}$ [1987] 2 MLJ 633 at 639
} 
trust. It is also a pre Reid case and if this issue is litigated again, the Malaysian courts will have to decide what path to follow.

Given the persuasive unanimous judgment of the apex court in FHR European Ventures and application of the proprietary rule on the unjust enrichment of trustees in the main common law jurisdictions ${ }^{33}$ it is strongly expected that Malaysia will follow these jurisdictions

\section{Bibliografi}

1. Chambers, R. (2013) Constructive trusts and breach of fiduciary duty.Conveyancer, 3, 241

2. Goode, R. (2011) Proprietary liability for secret profits - a reply. Law Quarterly Review, 127, 493;

3. Millet, P. (1993) Bribes and Secret Commissions. Restitution Law Review, 7

4. Millett,P. (2012) Bribes and secret commissions again. Cambridge Law Journal, 583

5. Smith, L (2013) Constructive trusts and the no-profit rule. Cambridge Law Journal, 72, 260

6. Worthington,S. (2013) Fiduciary Duties and Proprietary Remedies: Addressing the Failure of Equitable Formulae. Cambridge law Journal, 72,720.

${ }^{33}$ AG for Hong Kong v Reid 19941 AC 324 [New Zealand];Sumitomo Bank Ltd v Kartika Ratna Thahir [1993] 1 SLR 735.[Singapore]; Grimaldi $v$ Chameleon Mining NL (No 2) [2011] FCAFC 6 [Australia]; Insurance Corporation of British Columbia v Lo 278 DLR (4th) 148 applying Soulos v. Korkontzilas [1997] 2 SCR 217[Canada];

Daraydan Holdings Ltd \& Ors v Solland International Ltd \& Ors [2004] EWHC 622 (Ch) ; Fyffes Group Ltd. v Templeman \& Ors [2000] EWHC 224; Bhullar $v$ Bhullar [2003] EWCA Civ 424 [English cases would prefer to follow Reid]

United States v Carter 217 U.S. 286 (1910)[USA]. FHR European Ventures LLP \& Ors v Cedar Capital Partners LLC [2014] 4 All ER 79[England]. 